Article

\title{
Development of a Carbon Emissions Analysis Framework Using Building Information Modeling and Life Cycle Assessment for the Construction of Hospital Projects
}

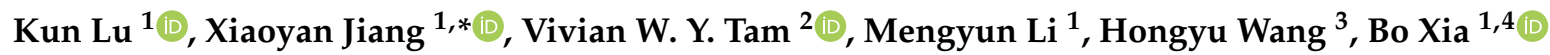 \\ and Qing Chen ${ }^{4}$ \\ 1 School of Civil Engineering, Hefei University of Technology, Hefei 230009, China; \\ lukun@mail.hfut.edu.cn (K.L.); limengyun@mail.hfut.edu.cn (M.L.); paul.xia@qut.edu.au (B.X.) \\ 2 School of Built Environment, Western Sydney University, Locked Bag 1797, Penrith, NSW 2750, Australia; \\ vivianwytam@gmail.com \\ 3 College of Urban and Environmental Sciences, Peking University, Beijing 100871, China; \\ hongyu_wang@pku.edu.cn \\ 4 School of Civil Engineering and Built Environment, Queensland University of Technology, Gardens Point, \\ Brisbane, QLD 4001, Australia; q28.chen@qut.edu.au \\ * Correspondence: jiangxiaoyan@hfut.edu.cn
}

Received: 7 September 2019; Accepted: 6 November 2019; Published: 8 November 2019 updates

\begin{abstract}
Buildings produce a large amount of carbon emissions in their life cycle, which intensifies greenhouse-gas effects and has become a great threat to the survival of humans and other species. Although many previous studies shed light on the calculation of carbon emissions, a systematic analysis framework is still missing. Therefore, this study proposes an analysis framework of carbon emissions based on building information modeling (BIM) and life cycle assessment (LCA), which consists of four steps: (1) defining the boundary of carbon emissions in a life cycle; (2) establishing a carbon emission coefficients database for Chinese buildings and adopting Revit, GTJ2018, and Green Building Studio for inventory analysis; (3) calculating carbon emissions at each stage of the life cycle; and (4) explaining the calculation results of carbon emissions. The framework developed is validated using a case study of a hospital project, which is located in areas in Anhui, China with a hot summer and a cold winter. The results show that the reinforced concrete engineering contributes to the largest proportion of carbon emissions (around $49.64 \%$ ) in the construction stage, and the HVAC (heating, ventilation, and air conditioning) generates the largest proportion (around 53.63\%) in the operational stage. This study provides a practical reference for similar buildings in analogous areas and for additional insights on reducing carbon emissions in the future.
\end{abstract}

Keywords: carbon emissions; building information modeling (BIM); life cycle assessment (LCA); analysis framework; Chinese hospital; carbon coefficient database; sustainable green building; hot summer; cold winter

\section{Introduction}

The concept of sustainability is now widely accepted on account of the threat of climate change and global warming [1,2]. One of the predominant causes of climate change and global warming is the increase in carbon emissions [3,4]. As a core industry, the construction industry accounts for about $30 \%-40 \%$ of carbon emissions of all industries combined $[5,6]$. Based on this, the calculation and analysis of a building's carbon emissions helps not only to achieve the goal of reducing carbon emissions but also to achieve long-term sustainability [7]. 
The construction industry needs to calculate and analyze carbon emissions [8-10]. To this end, some scholars have used life cycle assessment (LCA) theory $[11,12]$ to define and calculate a building's life cycle carbon emissions (BLCCE) $[13,14]$. Other scholars have combined building information modeling (BIM) and life cycle assessment (LCA) to develop frameworks for a building's carbon emissions $[4,15,16]$. However, these frameworks have mainly focused on the calculation of carbon emissions and have often ignored BLCCE analysis.

In the past, the research on a building's carbon emissions was limited to developed countries, such as the United States [17], the United Kingdom [18], and Sweden [19]. In recent years, Chinese scholars have also begun to pay attention to the carbon emissions of buildings $[4,14,15,20,21]$. These studies have included the BLCCE of villas [4], residences [14,20,21], and office buildings [14,15]. However, since different types of buildings lead to different levels of carbon emissions [7,22], research on medical buildings cannot be neglected.

In addition, carbon emissions are also related to the local climate of the buildings [22,23]. Previous studies have concentrated on warm climates [24], tropical desert climates [25], and subfrigid climates [19]. The object of this study, the Anhui province of China, has the typical monsoon climate of a medium-latitude region, with a hot summer and a cold winter [26], but there is no precedent research focusing on such an area for the carbon emissions analysis of buildings.

More importantly, the carbon emission coefficients (CECs), which represent the amount of carbon emissions emitted per unit of consumption, affect the calculation results of carbon emissions [21]. In China, some scholars have provided various CECs of Chinese building materials (including 15 CECs involved in Peng's study [15] and 14 CECs provided by Zhang and Wang [14]), and some have adopted the CECs of the existing LCA software (such as eBalance used by Yang [4]). Unfortunately, these CECs are not comprehensive, and it is necessary to establish a more complete CEC database for Chinese buildings.

Based on the deficiencies of the above studies, this study makes the following assumptions:

(1) An analysis framework of BLCCE based on BIM and LCA can be used to evaluate the carbon emissions composition after calculating carbon emissions and provide a quantitative basis for the adoption of low-carbon measures.

(2) Using a hospital in the Anhui province of China as a case study, the framework will provide a valuable reference for hospital buildings, as well as for buildings in areas with a hot summer and a cold winter.

(3) An expanded CEC database of buildings will provide the basis for future research and a practical application in China.

It is worth noting that this paper adopts process-based LCA, and the boundary of BLCCE in this paper is determined according to the research of Peng [15]. The calculation unit is a carbon dioxide equivalent $\left(\mathrm{CO}_{2}\right.$-eq), which takes into account the contribution of greenhouse gases (including $\mathrm{CO}_{2}$, $\mathrm{CH}_{4}$, and $\mathrm{NO}_{2}$ ) [27].

\section{Literature Review}

\subsection{LCA in the Building Sector}

Life cycle assessment (LCA) is a method of assessing the environmental loads of products during their life cycle $[11,12,28]$. In a broad sense, there are three types of LCA approaches: process-based, economic input-output (EIO), and hybrid [29]. The process-based analysis is a commonly used bottom-up method, which involves identifying all materials and energy flows associated with different activities involved in the production and quantifying the corresponding environmental impacts [30]. The method accounts for the majority of studies in the fields of construction technology due to its accuracy and detailed process [29]. Contrary to the process-based LCA, economic input-output analysis is a top-down LCA method [30]. The strength of this method lies in its ability to account for all indirect impacts involved in the supply chain of a product or service on top of the direct environmental impacts [30,31]. The hybrid method was developed by combining the advantages of the process-based and EIO approaches [32]. 
The process-based LCA is highly encouraged by the International Organization for Standardization (ISO) standards due to its accuracy and detailed process [32]. According to ISO 14040 and ISO 14041, LCA research is divided into four steps [12,33]: (1) goal and scope definition: defining the goal, scope, and boundary of the LCA research [33]; (2) inventory analysis (life-cycle inventory): collecting the data on energy and material consumption and creating an input or output inventory [9]; (3) environment impact assessment (life-cycle impact assessment): measuring the flow to be summed for an overall impact category total [33]; (4) interpretation: quantifying and evaluating the research results of life-cycle inventory and life-cycle impact assessment and originating conclusions and suggestions [34].

The application of LCA in a building field is multi-faceted and involves the rating of sustainable green buildings, energy assessment, building refurbishments, cost, social assessment, and carbon emissions [35]. Some scholars have applied LCA to the rating of sustainable green buildings, which encouraged building sustainability assessment in practice [36,37]. Some scholars have applied LCA to the energy assessment of buildings, with their ultimate purpose to formulate strategies to reduce primary energy use in buildings $[5,13,38]$. The purpose of applying LCA to building refurbishments is to choose building retrofit measures with low life cycle environmental impacts [39-41]. Some studies have integrated LCC (life cycle cost), LCA, and social LCA and have performed life cycle sustainability assessment [42-44]. Moreover, in order to seek strategies to reduce the global warming effect, some scholars have evaluated carbon emissions in buildings [4,15], and this will be discussed further in Section 2.2.

\subsection{Applying LCA to BLCCE}

All three types of LCA methods (i.e., process-based, EIO, and hybrid) have been applied to the carbon emission of buildings. Due to the detailed characteristics of the product, the process-based methodology accounts for the majority of studies in carbon emissions of building [29], such as the research of Yang et al. [4] and Peng [15]. For studies with mass data, such as the carbon emission of buildings in the whole city, the EIO method is convenient, as Yan et al. showed [31]. In addition, the hybrid method is used in the calculation of BLCCE by combining the advantages of the above two methods, as shown in the previous literature $[45,46]$.

The applications of process-based LCA to carbon emissions of a building provided an accurate and detailed process [29]. Some scholars have put forward the concept of a building's life cycle carbon emissions (BLCCE) [15], which are divided into three stages: the construction stage (the embodied stage), the operational stage, and the demolition stage $[7,15]$. Carbon emissions at the construction stage mainly include material production, material transportation, and construction on site $[4,47]$. The carbon emissions at the operational stage are caused by the consumption of energy in HVAC (heating, ventilation, and air conditioning), lighting, water supplying, and equipment use [48]. Carbon emissions at the demolition stage mainly come from demolition and refurbishment [15]. The composition of BLCCE is shown in Figure 1.

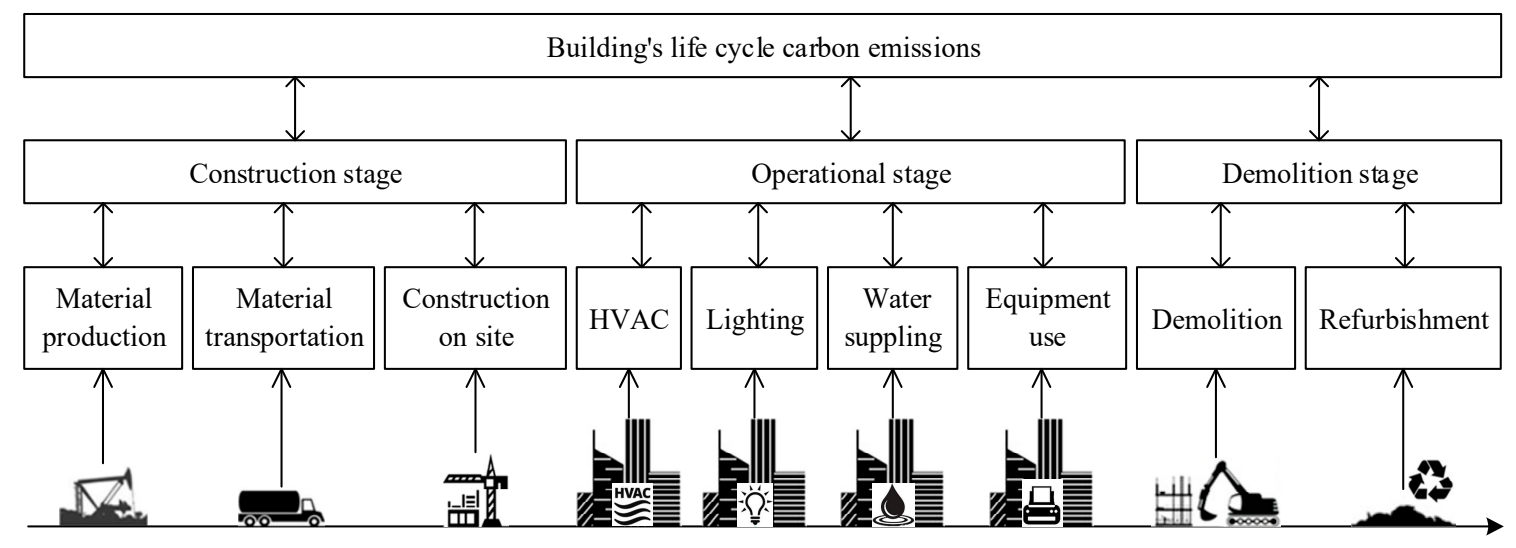

Figure 1. Composition of a building's life cycle carbon emissions (BLCCE). 
However, process-based LCA requires extensive data that are often restored in multiple, disparate, and proprietary sources [29]. Consequently, this approach may lead to assumptions, high costs, and significant time investment [49]. During the construction phase, different types of material, various types of machines and chaotic construction techniques are densely mixed together in a short period of time [50], which leads to difficulties in calculation. In the operational stage, carbon emissions vary greatly with climate conditions, comfort requirements, and operational schedules [22], which also leads to difficulties in obtaining data. All these characteristics make the calculation of BLCCE difficult.

\subsection{Integration of LCA and BIM in BLCCE}

It is generally known that the calculation of BLCCE requires high costs and significant time investment [35,51], but BIM can reduce the time and effort required to manage building information and LCA data $[16,52]$. An increasing number of scholars have presumed that connecting BIM and LCA software could eliminate the need for manual data input and remarkably accelerate the establishment of the LCA model [52-54].

A quantities calculation sheet based on BIM can directly reflect the consumption of materials and machineries, which can effectively manage multiple data in the construction stage [4,9]. In addition, BIM can reveal information about a building, including climate conditions, comfort requirements, and operational schedules, and the BIM-integrated energy consumption software also has the ability to simulate energy consumption in the operation stage $[7,15,19]$.

According to the review of BIM-based LCA by Soust-Verdaguer et al., most previous papers have been focused on carbon emissions calculation [16]. Many scholars have obtained relatively mature calculation methods by combining BIM and LCA $[4,15,33]$. Peng presented a calculation method for BLCCE based on Ecotect and BIM [15]. Yang et al. undertook a case study on the carbon footprint accounting of a residential building based on BIM and LCA [4]. Gardezi and Shafiq proposed an operational carbon footprint prediction model based on BIM and LCA [33]. These studies, rather than point out where carbon emissions came from (e.g., carbon emissions from activities of construction stage, from each month at operational stage), demonstrate how the total amount of carbon emissions can be calculated.

Of the limited carbon emissions analysis, for the construction stage, Lee et al. analyzed the carbon emissions generated by 13 work types and their proportion [9], while Yang et al. analyzed the proportion of carbon emissions generated by building materials [4]. For the operational stage, Najjar et al. analyzed the impact of cooling load on carbon emissions [34]. Schultz et al. compared the carbon emissions of buildings in different geographical locations [55]. For the demolition stage, the carbon emissions during the demolition stage only account for about $1 \%$ of the BLCCE [14], so the analysis is of limited significance [7]. These studies have achieved certain results, but most of them have not been combined with BIM. In addition, systematic analysis methods for BLCCE have not been established.

\subsection{Factors Related to BLCCE}

Factors that affect a building's carbon emissions mainly include (1) carbon emission coefficients (CECs), (2) building types, (3) structure schemes, and (4) geographical location and climate [30].

The CEC has a huge impact on the calculation of carbon emissions $[21,56]$. In many developed countries, there are relatively complete CEC databases, for example, Building for Environmental Economic Sustainability (BEES) in the United States, Impact Estimator for Buildings (IEB) in Canada, and Inventory of Carbon and Energy (ICE) in the United Kingdom [21]. In China, the eBalance based on the Chinese Life Cycle Database (CLCD) is the most commonly used CEC database [4,21]. In addition, the Chinese government has shared some CECs of construction materials and machinery in GB/T 51366-2019. Some scholars have also provided CECs of some major materials (including 15 CECs involved in Peng's study [15] and 14 CECs provided by Zhang and Wang [14]). However, these CECs were insufficient. Furthermore, most existing databases and tools do not take the characteristics of production (such as producing area and manufacturing technique) into account. 
Different building types have different users and schedules, which leads to different amounts of carbon emissions [7,22]. Previous studies have covered a variety of building types, including single-family villas $[4,57]$, apartments $[6,17]$, high-rise residences $[7,58]$, and office buildings $[14,15]$. However, there has been a lack of research on the BLCCE of hospital buildings.

Different structure schemes also have a significant impact on the BLCCE [14]. Zhang and Wang compared the differences between structures of brick-concrete, masonry-concrete, and reinforced concrete [14]. In addition, some scholars have also compared the carbon emissions between prefabricated structures and traditional structures [59-61]. In recent years, modern wood houses promoted the idea and application of environmentally and energetically efficient constructions $[62,63]$. Švajlenka and Kozlovská compared the modern construction system based on wood to the traditional structure system $[62,64]$.

Geographically, previous studies on the carbon emissions of buildings have included China [4,15, 65], the United States [17], the United Kingdom [18], Sweden [19], Saudi Arabia [25], and Korea [6]. Concerning the local climate of buildings [25,26], previous studies have focused on warm climates [27], tropical desert climates [28], and subfrigid climates [22]. However, research on areas with hot summers and cold winters in China has not been further developed.

\subsection{Research Gaps}

The literature review above shows that the research on BLCCE has achieved considerable development and that it is valuable to combine BIM with LCA, but it still needs to be coordinated and improved. The research gaps are as follows:

(1) Although many scholars have put forward carbon emissions frameworks that combine BIM and LCA, these frameworks have focused on the calculation of carbon emissions, while the analysis of carbon emissions is limited. Therefore, building on previous frameworks, this paper develops an analysis framework for carbon emissions.

(2) In terms of building types, previous studies in China only cover villas, apartments, and office buildings, and there is currently a lack of research on hospitals. This paper takes a hospital as a case study to fill this gap.

(3) Previous studies cover a variety of geographical locations and climate types; however, studies on areas with a cold winter and a hot summer are still missing. This paper, as the first case study of the Anhui province, which has a cold winter and a hot summer, will provide an effective reference for areas with a similar climate.

(4) At present, China's CEC suffers from a small database and a shortage of characterizations. In this study, 180 characteristic CECs of buildings were collected, which will greatly expand China's CEC database of buildings.

\section{Methodologies}

The goal of this study is to develop a carbon emissions analysis framework based on BIM-enabled LCA. The analysis framework is applied to a case study to quantify the carbon emissions of a hospital in China. This LCA study consists of four steps in accordance with the ISO 14040 \& 14041 standards: (1) goal and scope definition; (2) inventory analysis; (3) environment impact assessment; (4) interpretation.

Based on LCA and BIM, the methodology framework for the analysis of BLCCE is shown in Figure 2. 


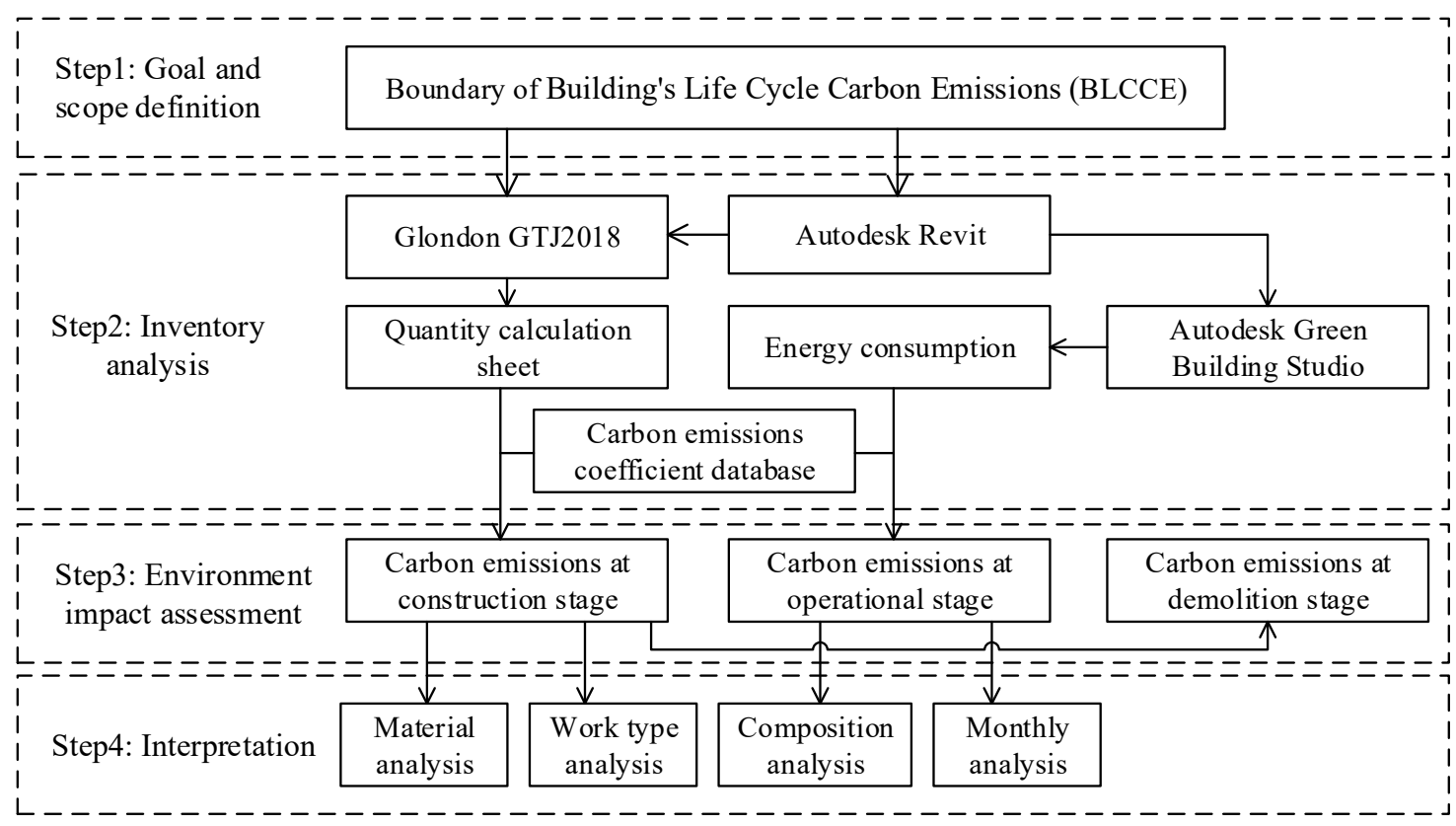

Figure 2. BIM-LCA based methodology framework for analyzing BLCCE.

\subsection{Goal and Scope Definition}

The goal and scope of the system must be firstly determined in LCA [9]. Currently, there is a lack of consensus in goal and scope definitions among various studies [35]. Based on previous studies [7,15], this study defines the boundary of BLCCE as the carbon emissions generated in the three stages of a building's life cycle. Specifically, it includes the construction stage (including material production, material transportation, and construction on site), the operational stage (including HVAC, lighting, water supplying, and equipment use), and the demolition stage (demolition and refurbishment). The detailed system boundary is illustrated in Section 2.2 and Figure 1. The definition of the system boundary provides the basis for creating BIM models and calculating carbon emissions.

\subsection{Inventory Analysis}

The second step in LCA is the inventory analysis, also known as life cycle inventory. In this step, we need to collect information about carbon emission coefficients, consumption (including man-days, materials, and machine consumption) at the construction stage, energy consumption at the operational stage, and so on [34].

In the life cycle inventory, the first step is to collect the carbon emission coefficient (CEC) database. A review was conducted about the carbon emissions of buildings based on the CNKI (China National Knowledge Infrastructure), which is the most comprehensive database of research publications in China [66]. Combined with GB/T 51366-2019 [67], 180 CECs were obtained, which can be found in Part 1 of the supplementary materials.

Afterwards, the BIM model was created for inventory analysis. The core BIM modeling software is Autodesk Revit2017, which is the most commonly used BIM modeling software in the field of AEC (architecture, engineering, and construction) [68,69]. By importing Autodesk Revit2017 into Glondon GTJ2018, a quantities calculation sheet is acquired through GTJ2018.

Additionally, Autodesk Green Building Studio, software commonly used for green building analysis $[34,70,71]$, is able to conduct energy simulation and determine fuel consumption and electricity consumption required at the operational stage [71]. We used Green Building Studio built by Revit to calculate the energy consumption during the operational stage.

The BIM model includes graphic information, materials data, and building components, and this information is defined by the LOD (level of detail) [16]. According to the American Institute of 
Architecture (AIA), the LOD defines the minimum content requirements for BIM at five progressively detailed levels of completeness, from LOD 100 to LOD 500 [52]. To ensure the accuracy of BIM, the BIM model is created with LOD 300, as suggested by Soust-Verdaguer et al. [16].

\subsection{Environment Impact Assessment}

The third step of the LCA is the environment impact assessment, also known as the life cycle impact assessment [70]. The BLCCE is calculated in this step to create simpler, convincing results [5]. The carbon dioxide equivalent $\left(\mathrm{CO}_{2}\right.$-eq) is often regarded as an accounting unit for carbon emissions $[4,7]$ because it takes into account the combined contribution of $\mathrm{CO}_{2}, \mathrm{CH}_{4}$, and $\mathrm{NO}_{2}$ as greenhouse gases [27].

According to the above analysis, the BLCCE is composed of carbon emissions generated in three stages. The total BLCCE is calculated by Equation (1). $C_{\text {tot }}, C_{\text {con }}, C_{\text {ope, }}$ and $C_{\text {dem }}$ correspond to the carbon emissions of the life cycle, the construction stage, the operational stage, and the demolition stage, respectively.

$$
C_{\text {tot }}=C_{\text {con }}+C_{\text {ope }}+C_{\text {dem }} .
$$

The carbon emissions at the construction stage are composed of a sub-item project and a measure project (see Equation (2)). The carbon emission of the sub-item project or the measure project is equal to the carbon emissions coefficient of the quota multiplied by the quantity of the quota (see Equation (3)). The carbon emission coefficient of the quota is equal to the amount of man-days, materials, and mechanical consumption, multiplied by their carbon emission coefficient (see Equation (4)).

$$
\begin{gathered}
C_{\text {con }}=\sum C_{\mathrm{sp}}+\sum C_{\mathrm{mp}} \\
C_{\mathrm{sp}, \mathrm{mp}}=\sum C C_{\mathrm{q}} \times Q_{\mathrm{q}} \\
C C_{\mathrm{q}}=\sum C C_{\mathrm{md}} \times Q_{\mathrm{md}}+\sum C C_{\text {mat }} \times Q_{\text {mat }}+\sum C C_{\text {mech }} \times Q_{\text {mech }} .
\end{gathered}
$$

In Equations (2)-(4): $C_{\mathrm{sp}}$ and $C_{\mathrm{mp}}$ represent carbon emissions generated by the sub-item project and the measure project, respectively; $C C_{\mathrm{q}}, C C_{\mathrm{md}}, C C_{\mathrm{mat}}$, and $C C_{\text {mech }}$ represent the carbon emission coefficient of the quota, the man-days, the materials, and the machine class, respectively; $Q_{\mathrm{q}}, Q_{\mathrm{md}}$, $Q_{\text {mat }}$, and $Q_{\text {mech }}$ represent the quota, amount of man-days, the amount of materials, and the machine class, respectively.

Carbon emissions at the operational stage are mainly generated from the energy consumption of HVAC, lighting, water supplying, and equipment use. This energy consumption is totally represented by fuel consumption and electricity consumption. If sustainable energy is used at the operational stage, this part should be deducted. The formulas of carbon emissions at the operational stage are listed in Equations (5) and (6).

$$
\begin{gathered}
C_{\text {ope }}=C_{\text {sy }} \times Y \\
C_{\text {sy }}=C C_{\mathrm{f}} \times\left(Q_{\mathrm{f}}-Q_{\mathrm{f}, \mathrm{re}}\right)+C C_{\mathrm{e}} \times\left(Q_{\mathrm{e}}-Q_{\mathrm{e}, \mathrm{re}}\right) .
\end{gathered}
$$

In Equations (5) and (6), $C_{\text {sy }}$ represents the annual carbon emissions generated during the building use phase; $Y$ is the service life at the operational stage. $C C_{\mathrm{f}}$ and $C C_{\mathrm{e}}$ represent the carbon emission coefficient of fuel and electricity, respectively; $Q_{\mathrm{f}}, Q_{\mathrm{f}, \mathrm{re}}, Q_{\mathrm{e}}$, and $Q_{\mathrm{e}, \text { re }}$ represent the amount of fuel consumption, the reduction of fuel consumption, the amount of electricity consumption, and the reduction of electricity consumption, respectively.

As for the demolition stage, many scholars have pointed out that carbon emissions of the demolition stage account for about $1 \%$ of the BLCCE [14]. To facilitate calculation, the demolition stage can be estimated to be equal to $10 \%$ of the construction stage [72,73]. The estimation formula at the demolition stage can be seen in Equation (7).

$$
C_{\mathrm{dem}}=C_{\mathrm{con}} \times 10 \%
$$




\subsection{Interpretation}

The final step in the LCA is interpretation. This step produces conclusions, highlights environmental issues, clarifies the results of the analysis, and provides recommendations $[33,34]$. In the interpretation, four analysis modules are carried out on the carbon emissions of buildings, focusing on the construction stage and the operational stage. Because the carbon emissions in the demolition stage only account for around $1 \%$ of the BLCCE, it has limited contributions for its analysis. Therefore, this study will not be considered for the demolition stage. The four analysis modules are as follows:

(1) Carbon emissions analysis of construction material at the construction stage. This module analyzes the contribution of various material types for carbon emissions and their percentages of the construction stage.

(2) Carbon emissions analysis of work types at the construction stage. This module analyzes the building types for assessing their carbon emissions and their percentages of the construction stage.

(3) Composition analysis of carbon emissions at the operational stage. This module assesses the annual carbon emissions from HVAC, lighting, water supplying, and equipment use in the operational stage and the percentages of annual carbon emissions.

(4) Monthly analysis of carbon emissions at the operational stage. This module assesses the amount of carbon emissions per month and its composition over a year.

\section{Case Study}

\subsection{Background Information of the Hospital Building}

The hospital is located in Chuzhou City, Anhui Province, China. Chuzhou has the typical monsoon climate of a medium-latitude area with a hot summer and a cold winter [26], with a maximum temperature of $38^{\circ} \mathrm{C}$ in the summer and a minimum temperature of $-7^{\circ} \mathrm{C}$ in the winter. This hospital is a public building with a reinforced concrete frame structure system. The gross floor area (GFA) is $6367 \mathrm{~m}^{2}$, and the base area is $1703 \mathrm{~m}^{2}$. The four-storey building of $15.9 \mathrm{~m}$ has 102 beds, and it is centrally heated by fuel energy in the winter. The construction stage, operational stage, and demolition stage are estimated to occupy 2,50 , and 0.5 years, respectively. The appearance of the building is shown in Figure 3.

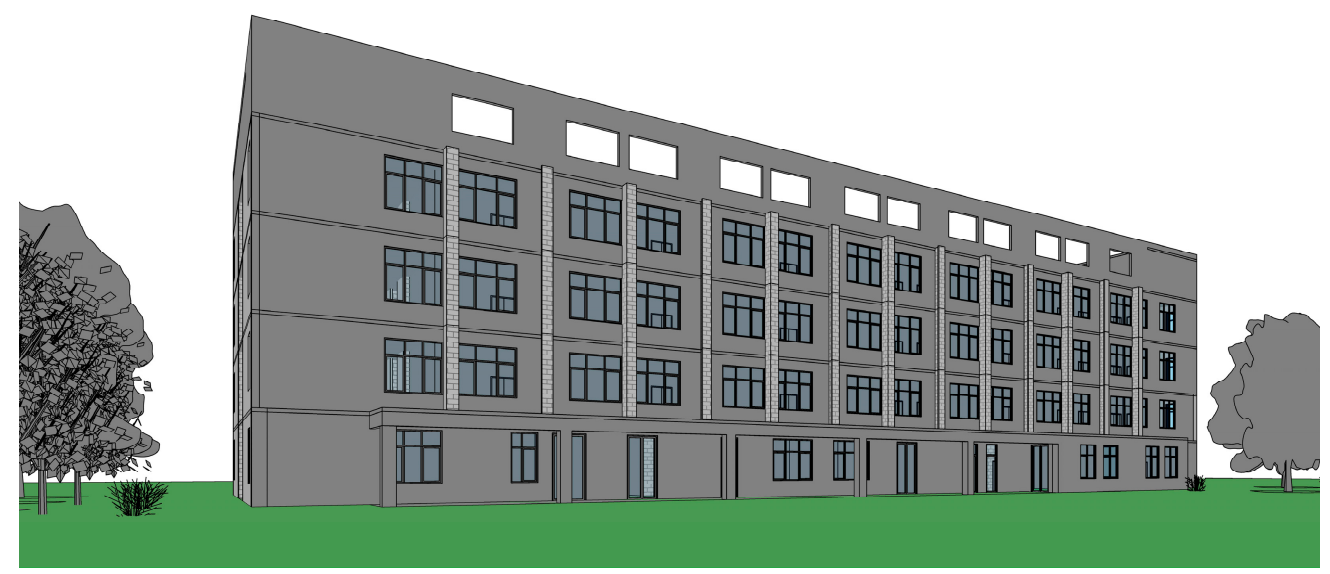

Figure 3. Architectural appearance (building information modeling (BIM) in Revit).

\subsection{Calculation Result of Carbon Emissions}

A BIM model in Revit (as shown in Figure 3) was constructed to obtain the quantity calculation sheet from GTJ2018 (as shown in the supplementary materials, Part 2), which contained 13 work types and 126 sub-item projects. In addition, the main material list was also obtained (as shown in Table 1). Multiplied by the corresponding CEC, the amount of carbon emissions in the construction stage is $3166.78 \mathrm{tCO}_{2}$-eq. 
Table 1. Main material and their consumption.

\begin{tabular}{|c|c|c|c|c|c|}
\hline Material Name & Unit & Amount & Material Name & Unit & Amount \\
\hline $\begin{array}{l}\text { C15 commercial concrete (no } \\
\text { pumping) }\end{array}$ & $\mathrm{m}^{3}$ & 220.41 & Colored glazed floor tile & $\mathrm{m}^{2}$ & 217.43 \\
\hline $\begin{array}{l}\text { C30 commercial concrete } \\
\text { (pumping) }\end{array}$ & $\mathrm{m}^{3}$ & 1915.57 & Floor tile $300 \times 300$ & $\mathrm{~m}^{2}$ & 399.29 \\
\hline $\begin{array}{l}\text { C30 commercial concrete (no } \\
\text { pumping) }\end{array}$ & $\mathrm{m}^{3}$ & 21.41 & $\begin{array}{l}\text { Polycrystalline anti-slip } \\
\text { floor tile } 300 \times 300\end{array}$ & $\mathrm{~m}^{2}$ & 1420.89 \\
\hline $\begin{array}{l}\text { C20 commercial concrete (no } \\
\text { pumping) }\end{array}$ & $\mathrm{m}^{3}$ & 317.68 & $\begin{array}{l}\text { Polycrystalline anti-slip } \\
\text { floor tile } 600 \times 600\end{array}$ & $\mathrm{~m}^{2}$ & 3341.29 \\
\hline $\begin{array}{l}\text { C35 commercial concrete } \\
\text { (pumping) }\end{array}$ & $\mathrm{m}^{3}$ & 52.59 & Granite plate $10 \mathrm{~cm}$ & $\mathrm{~m}^{2}$ & 6.85 \\
\hline $\begin{array}{c}\text { C40 commercial concrete } \\
\text { (pumping) }\end{array}$ & $\mathrm{m}^{3}$ & 63.07 & Granite plate $3 \mathrm{~cm}$ & $\mathrm{~m}^{2}$ & 5.28 \\
\hline Steel pipe & $\mathrm{t}$ & 3.93 & Granite plate $4 \mathrm{~cm}$ & $\mathrm{~m}^{2}$ & 210.77 \\
\hline Steel bar ( $\Phi 10$ or less) & $\mathrm{t}$ & 115.03 & Granite plate (other size) & $\mathrm{m}^{2}$ & 516.99 \\
\hline Steel bar (more than $\Phi 10$ ) & $\mathrm{t}$ & 230.44 & Petroleum asphalt & $\mathrm{kg}$ & 5684.45 \\
\hline Steel support & $\mathrm{kg}$ & 6500.76 & $\begin{array}{l}\text { SBS-modified asphalt } \\
\text { waterproofing roll }\end{array}$ & $\mathrm{m}^{2}$ & 2481.37 \\
\hline Welding rod & $\mathrm{kg}$ & 2791.04 & Water & $\mathrm{m}^{3}$ & 2765.60 \\
\hline Structural Steel & $\mathrm{kg}$ & 70.60 & $\begin{array}{c}\text { Crushed stone (particle } \\
\text { size } 40 \text { ) }\end{array}$ & $\mathrm{t}$ & 279.77 \\
\hline Nails & $\mathrm{kg}$ & 2726.10 & Crushed stone (other size) & $\mathrm{t}$ & 59.26 \\
\hline $\begin{array}{l}\text { Expanded metal mesh (Steel } \\
\text { wire mesh) }\end{array}$ & $\mathrm{m}^{2}$ & 4054.64 & Light steel keel $600 \times 600$ & $\mathrm{~m}^{2}$ & 3316.32 \\
\hline Calcium silicate cement & $\mathrm{t}$ & 12.20 & $\begin{array}{l}\text { All-ceramic wall tile } 300 \times \\
450\end{array}$ & $\mathrm{~m}^{2}$ & 2757.28 \\
\hline Portland cement & $\mathrm{t}$ & 542.61 & $\begin{array}{c}\text { All-ceramic wall tile } 300 \times \\
600\end{array}$ & $\mathrm{~m}^{2}$ & 2133.20 \\
\hline Gypsum & $t$ & 34.96 & PVC-steel window & $\mathrm{m}^{2}$ & 1373.96 \\
\hline Standard brick $240 \times 115 \times 53$ & 100 blocks & 174.17 & Window-shades & $\mathrm{m}^{2}$ & 386.59 \\
\hline $\begin{array}{l}\text { Coal gangue standard brick } \\
\qquad 240 \times 115 \times 53\end{array}$ & 100 blocks & 161.94 & Class-A fire-proof door & $\mathrm{m}^{2}$ & 9.66 \\
\hline $\begin{array}{l}\text { Coal gangue solid brick } 240 \times \\
\qquad 115 \times 53\end{array}$ & 100 blocks & 23.56 & Class-B fire-proof door & $\mathrm{m}^{2}$ & 45.99 \\
\hline Cork brick $240 \times 115 \times 90$ & 100 blocks & 1679.73 & Class-C fire-proof door & $\mathrm{m}^{2}$ & 49.32 \\
\hline $\begin{array}{c}\text { Coal gangue cork brick } 240 \times \\
180 \times 115\end{array}$ & 100 blocks & 2096.15 & Compound wood template & $\mathrm{m}^{2}$ & 4285.90 \\
\hline
\end{tabular}

According to the energy consumption analysis of Green Building Studio (as shown in the supplementary materials, Part 2), the annual electricity consumption in the operational stage is $1,340,260 \mathrm{kWh}$, and the fuel consumption is 3,169,999 MJ (as shown in Table 2). The amount of the carbon emissions generated by electricity consumption is $586 \mathrm{tCO}_{2}-\mathrm{eq} / \mathrm{y}$, the carbon emissions generated by fuel consumption total $158 \mathrm{tCO}_{2}-\mathrm{eq} / \mathrm{y}$, and the reduction of roof solar energy to carbon emissions is $-12 \mathrm{tCO}_{2}-\mathrm{eq} / \mathrm{y}$. The amount of total carbon emissions in the building operation stage is $732 \mathrm{tCO}_{2}$-eq/y. Multiplied by the 50-year operational stage, the carbon emissions generated in the operation stage are $36,600 \mathrm{tCO}_{2}$-eq.

Table 2. Energy consumption in the operational stage.

\begin{tabular}{cccccc}
\hline Energy Consumption & HVAC & Lighting & Water Suppling & Equipment Use & Total \\
\hline Fuel consumption $(\mathrm{MJ})$ & $2,999,421$ & 0 & 170,578 & 0 & $3,169,999$ \\
Electricity consumption $(\mathrm{kWh})$ & 570,736 & 270,864 & 0 & 498,660 & $1,340,260$ \\
\hline
\end{tabular}

The amount of the carbon emissions in the demolition stage is estimated at $10 \%$ of that in the construction stage, and the result is $316.69 \mathrm{tCO}_{2}$-eq. By summarizing these three stages, the amount of BLCCE is $40083.56 \mathrm{tCO}_{2}$-eq. After obtaining the carbon emissions of each stage, the percentage of each stage in BLLCE and the annual average carbon emission of each working area $C_{\mathrm{At}}\left(\mathrm{kgCO}_{2}-\mathrm{eq} /\left(\mathrm{m}^{2} \cdot \mathrm{y}\right)\right)$ 
are calculated, as shown in Table 3. A detailed calculation process can be found in the supplementary materials and in [72].

Table 3. Calculation result of the BLCCE.

\begin{tabular}{cccc}
\hline Stage & $\begin{array}{c}\text { Carbon Emissions } \\
\left(\mathbf{t C O}_{\mathbf{2}}-\mathbf{e q}\right)\end{array}$ & $\begin{array}{c}\text { Percentage } \\
\mathbf{( \% )}\end{array}$ & $\begin{array}{c}\boldsymbol{C}_{\mathrm{At}} \\
\mathbf{( k g C O}_{\mathbf{2}}-\mathbf{e q} /\left(\mathbf{m}^{\mathbf{2}} \mathbf{y}\right) \mathbf{)}\end{array}$ \\
\hline Construction stage & 3166.87 & 7.90 & 248.69 \\
Operational stage & $36,600.00$ & 91.31 & 114.97 \\
Demolition stage & 316.69 & 0.79 & 99.48 \\
Total & $40,083.56$ & 100.00 & 119.91 \\
\hline
\end{tabular}

\subsection{Carbon Emissions Analysis of Construction Materials at the Construction Stage}

The top 10 building materials that contribute the most carbon emissions are listed in Figure 4. The cumulative amount of the carbon emissions generated by these 10 materials reaches $2043.2 \mathrm{tCO}_{2}$-eq, accounting for $65.28 \%$ of the total carbon emissions during the construction stage. It is found that concrete, steel, and cement contribute the most to the carbon emissions in the construction stage, reaching $848.1 \mathrm{tCO}_{2}$-eq $(26.78 \%), 799.3 \mathrm{tCO}_{2}$-eq $(25.24 \%)$, and $282.3 \mathrm{tCO}_{2}$-eq $(8.92 \%)$, respectively.

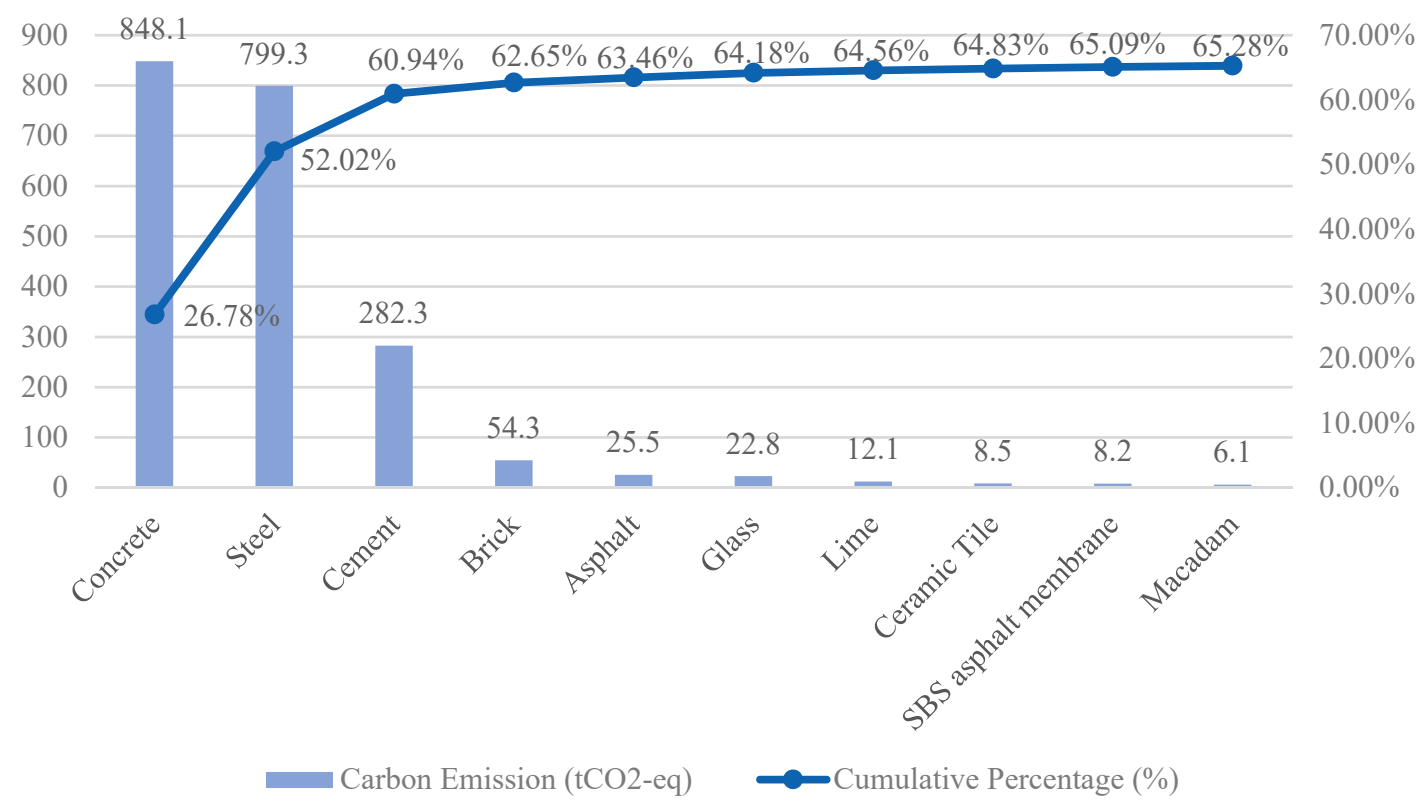

Figure 4. Carbon emissions data of the top 10 construction materials at the construction stage.

The reason is not difficult to find, because the case building is a reinforced concrete structure, consuming a high amount of concrete $\left(2590.7 \mathrm{~m}^{3}\right)$, steel $(399,650.5 \mathrm{~kg})$, and cement $(524,755.1 \mathrm{~kg})$. In addition, their carbon emission coefficients are very high. For example, the carbon emission coefficient of $\mathrm{C} 20$ concrete is $239.19 \mathrm{kgCO}$-eq $/ \mathrm{m}^{3}$, the carbon emission coefficient of $\mathrm{C} 30$ is $346.95 \mathrm{kgCO}-\mathrm{eq} / \mathrm{m}^{3}$, the carbon emission coefficient of steel is $2.10 \mathrm{kgCO}_{2}-\mathrm{eq} / \mathrm{kg}$, and the carbon emission coefficient of cement is $0.54 \mathrm{kgCO}_{2}-\mathrm{eq} / \mathrm{kg}$. Because of the higher consumption and the higher carbon emission coefficient of these materials, the total amount of carbon emissions produced is large.

In addition to these three items, bricks, asphalt, glass, and other building materials also significantly contribute to carbon emissions during the construction stage.

\subsection{Carbon Emissions Analysis of Work Type at the Construction Stage}

There are 13 work types in the quantity calculation sheet, and their carbon emissions are shown in Figure 5. Of the 13 work types, the top 5 that generate the most carbon emissions are reinforced 
concrete engineering, metope adornment, brick engineering, floor decoration, and waterproof roofing. The amount of the carbon emissions generated by these five items is $1572.1 \mathrm{tCO}_{2}$-eq, $480.7 \mathrm{tCO}_{2}$-eq, $324.9 \mathrm{tCO}_{2}$-eq, $197.6 \mathrm{tCO}_{2}$-eq, and $168.5 \mathrm{tCO}_{2}$-eq, respectively, accounting for 49.64, 15.18, 10.26, 6.24, and $5.32 \%$ of the carbon emissions during the construction stage.

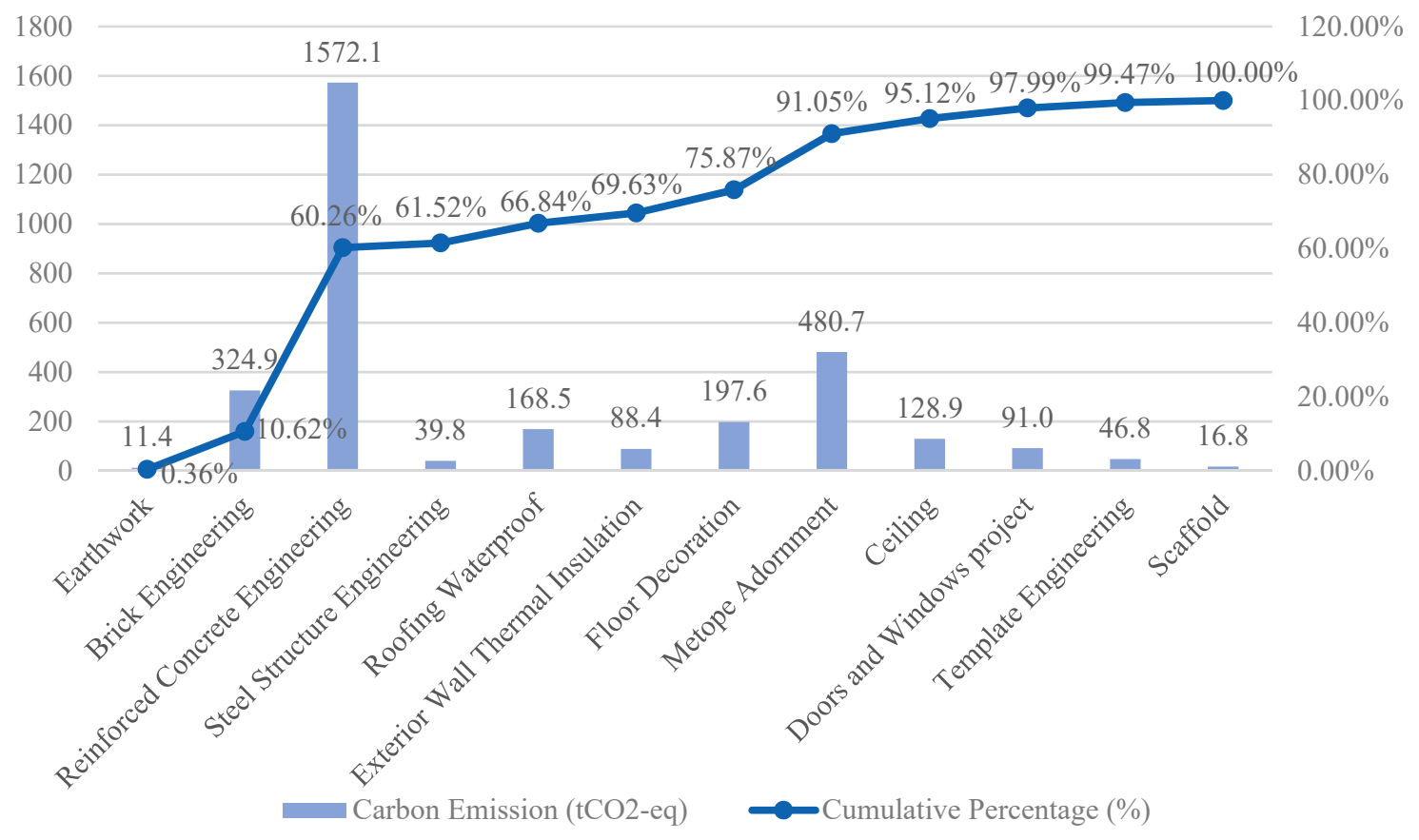

Figure 5. Carbon emissions data of 13 work types at the construction stage.

It was found that the maximum proportion by reinforced concrete engineering is $49.64 \%$, which means that almost half of the carbon emissions in the construction stage is made up of reinforced concrete. As the building consumes a large amount of concrete and steel, it has thus the greatest sources of carbon emissions for this project.

Brick engineering requires high amounts of bricks and cement, and waterproof roofing requires the styrene-butadiene-styrene (SBS) asphalt membrane. Brick, cement, and the SBS asphalt membrane are the main materials producing carbon emissions, so these two work types produce large carbon emissions.

In addition, it is necessary to pay special attention to metope adornment and floor decoration. They also produce a large amount of carbon emissions, which is related to the building type of the hospital. Since the walls and floors of the hospital buildings were decorated with stone and ceramic tiles, the production and construction of these materials will generate carbon emissions.

\subsection{Composition Analysis of Carbon Emissions at the Operational Stage}

The carbon emissions in the operational stage consist of HVAC (heating, initiation, and air conditioning), lighting, water supplying, and equipment use, and the amount of the annual carbon emissions and its percentages are as follows: $399.0 \mathrm{tCO}_{2}$-eq $(53.63 \%), 118.4 \mathrm{tCO}_{2}$-eq $(15.92 \%), 8.5 \mathrm{tCO}_{2}$-eq $(1.14 \%)$, and $218.0 \mathrm{tCO}_{2}$-eq (29.3\%), as displayed in Figure 6. Among them, HVAC, which accounts for the largest proportion during the operational stage, produces $149.5 \mathrm{tCO}_{2}$-eq from fuel consumption and $249.5 \mathrm{tCO}_{2}$-eq from electricity. 


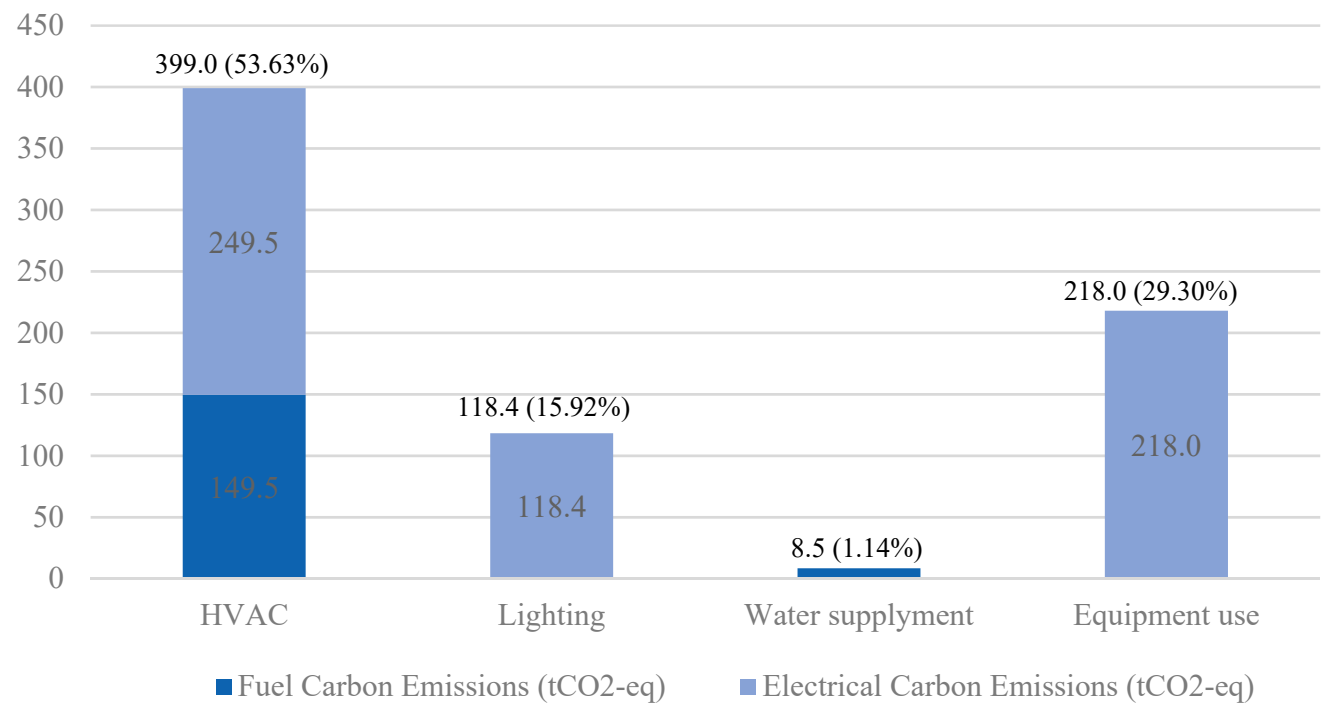

Figure 6. Composition of annual carbon emissions at the operational phase.

\subsection{Monthly Analysis of Carbon Emissions at the Operational Stage}

The carbon emissions generated each month and their composition were analyzed (as shown in Figure 7). The carbon emissions produced in the winter (December, January, and February) and the summer (June, July, and August) is $240.9 \mathrm{tCO}_{2}$-eq and $193.4 \mathrm{tCO}_{2}$-eq, respectively, which is significantly increased from $159.3 \mathrm{tCO}_{2}$-eq in the spring (March, April, and May) and $150.5 \mathrm{tCO}_{2}$-eq in the autumn (September, October, and November).

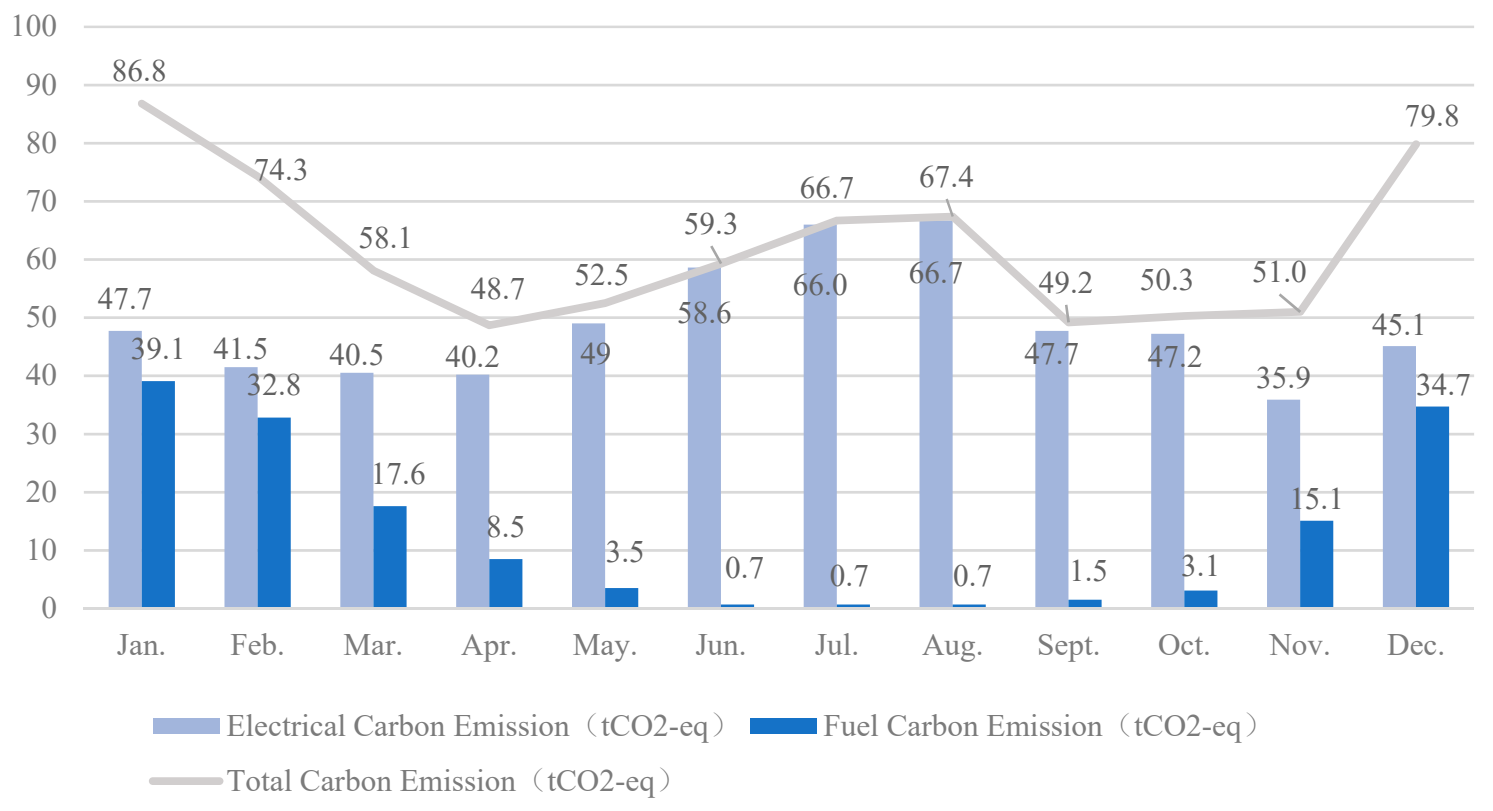

Figure 7. Monthly data of carbon emissions at the operational stage.

This is not difficult to explain, because Anhui Province is in a typical region with a hot summer and a cold winter, where the highest temperature in the summer is expected to be $38^{\circ} \mathrm{C}$, and the lowest temperature in the winter is expected to be $-7^{\circ} \mathrm{C}$. In order to maintain a suitable temperature inside the building in the winter and the summer, a large amount of energy will be consumed, which will generate a large amount of carbon emissions.

Fuel carbon emissions mainly come from HVAC (Figure 6), and the case building is centrally heated by fuel energy in the winter, so the amount of carbon emissions produced by fuel in the winter 
is relatively high (Figure 7). In the summer, air conditioning electricity is used for lowering the indoor temperature, so the electricity produces additional carbon emissions in the summer.

\section{Discussion}

Combined with BIM and LCA, this study proposes an analytical framework for a BLCCE. The calculation method in this framework is fast and efficient, and the four modules in interpretation can be used to analyze a building's carbon emissions in the construction stage and the operational stage. With the promotion of BIM [74] and LCA [4], this framework will be widely adopted in the future.

\subsection{Discussion of Methods}

The integration of BIM during the design stage makes design decisions more reasonable, because the quality, speed, and availability of design data have been improved [75]. The integration of BIM-LCA also help designers and engineers to obtain quick and reliable results about the environmental performance of buildings, since the early stages of design [16]. The framework proposed in this paper can simulate the results of the BLCCE at early stages of the building design, which can be used to evaluate the performance of buildings and select solutions that can minimize carbon emissions. In addition, wastage due to inefficiencies or mistakes in the project delivery process can also be reduced [75], which helps reduce carbon emissions.

Eleftheriadis et al. have asked this question: "How can structural engineers and architects collectively specify design solutions during the early design stages that optimize the life cycle performance of the building in a cost-effective and practical manner?" [76]. This question corresponds to an example in practice: designers can use materials with better insulation to reduce carbon emissions during the operational phase, which will generate more carbon emissions during the construction phase [7]. Designers can use this method to compare the BLCCE before and after adopting low-carbon measures, so as to quantify the reduction of BLCCE.

In addition, echoing the research on different structure schemes [14,59-63], this method can also be used to evaluate the difference in carbon emissions between different building structure schemes. When other factors are similar, the structural designer can choose a reasonable structure scheme based on the reduction of carbon emissions.

This framework, nevertheless, also has some shortcomings in the industry context of China currently, including the following:

(1) In China, CAD plane drawings are often utilized as the basis of engineering [74]. Secondary modeling is required from CAD drawings to the BIM model, which is time-consuming.

(2) Interoperability in BIM is a key aspect [16]. However, there is component and information loss in the transition of Autodesk Revit to Glondon GTJ2018 [72]. The compatibility between different BIM software has not been completely solved [7], which affects the results of quantities calculation sheet, so it needs to be checked, corrected, and supplied.

(3) The database of carbon emission coefficients has an impact on the calculation results $[21,56]$. Due to the lack of carbon emission equivalent coefficients of some materials in China, this study adopts the carbon emission coefficients that only consider $\mathrm{CO}_{2}$ for certain material types, which affects the calculation results in this study. However, this problem can be solved with academic research on China's carbon dioxide equivalent coefficients.

\subsection{Discussions of the Case Study}

In the carbon emissions during the construction stage, the contribution of concrete and steel to carbon emissions is substantial, which is consistent with the research of many scholars [4,7]. Reinforced concrete engineering accounts for the highest proportion among all work types, which is consistent with Lee et al.'s research [9]. However, the ratio of reinforced concrete work (49.64\%) is lower than that of $71.21 \%$ in Lee's study [9]. The reason may be that the decoration work in this case is relatively complex and generates additional carbon emissions. 
The proportion of carbon emissions from decoration work (mainly metope adornment and floor decoration) is diverse for different building types. In both the hospital in this case study and the villa in a case study of Yang et al. [4], the proportion of carbon emissions from the decoration is relatively large because they adopted complex or high-grade decorations. However, the amount of carbon emissions generated by the decoration of ordinary houses is relatively low [20,72].

Compared with some studies in other countries [46,77], the percentage of the carbon emissions in the operational stage is between $85.0 \%$ and $99.6 \%$, which is similar to the result of carbon emissions in this hospital case (91.31\%). Compared with other studies in China, the ratio of villas [4], residences [14,20,21], and office buildings [14,15] in the operational stage are $68.92 \%, 63.26 \% \sim 85.16 \%$, and $84.91 \% \sim 85.43 \%$ respectively. The carbon emissions proportion of the hospital building is higher than that of other building types during the operational stage. The possible reasons for this can be explained as follows:

(1) The case building is located in Anhui Province, which has a cold winter and a hot summer [26]. Compared with other areas, summer cooling and winter heating in this area require higher energy consumption.

(2) The daily operation time of hospitals is longer than that of other buildings. For example, the emergency department is open $24 \mathrm{~h}$ per day. The operation time will lead to an increase in carbon emissions caused by HVAC, lighting, and equipment use.

(3) The hospital building serves the population of the whole city, and the number of daily clients and staffs is higher than that of villas, residences, and office buildings. In addition, the patient's comfort demand is high, which further increases the burden of energy consumption.

\section{Conclusions}

In past research, the overall analysis framework of a building's life cycle carbon emissions (BLCCE) was often neglected. In addition, research on the carbon emissions of hospital buildings in areas with a cold winter and a hot summer is lacking. Moreover, carbon emissions coefficients of buildings have been insufficient, and characterization is lacking.

The main contributions of this study are as follows: (1) An analysis framework based on building information modeling (BIM) and life cycle assessment (LCA) is proposed to analyze BLCCE. (2) The hospital case study provides useful references for similar buildings in analogous areas and provides additional insights on reducing the BLCCE in the future. (3) This paper gives a comprehensive review of the carbon emission coefficients (CECs) in China's construction industry and provides 180 CECs that lend some help towards future research on carbon emissions.

The result of this case study showed that the amount of the carbon emissions generated in the construction, operation, and demolition stages of the hospital are $3166.8 \mathrm{tCO}_{2}$-eq $(7.90 \%)$, $36,600.0 \mathrm{tCO}_{2}$-eq $(91.31 \%)$, and $316.7 \mathrm{tCO}_{2}$-eq $(0.79 \%)$, respectively. Due to the large amount of carbon emissions generated from steel and concrete, the reinforced concrete engineering contributes the most carbon emissions during the construction stage. In the operational stage, HVAC produces the largest amount of carbon emissions, accounting for $53.63 \%$. The reason is related to a geographical location that has a hot summer and a cold winter, as well as the characteristics of the hospital building.

For future research, the following directions deserve scholarly attention:

(1) The compatibility between BIM and BIM-based software has not been completely solved, which has to be improved in the future.

(2) Although 180 CECs of China's building industry have been collected, further work is needed to expand the CEC database.

(3) Specific low-carbon measures should be tested to quantify their reduction of BLCCE. For example, how much of a reduction in BLCCE can be achieved by using wood, natural insulation materials, and so on?

(4) In China, owners have little interest in reducing the carbon emissions of their buildings. How can owners' willingness to reduce carbon emissions increase? 
Supplementary Materials: The following are available online at http://www.mdpi.com/2071-1050/11/22/6274/s1. Table S1: China's carbon emission coefficient database for construction of building. Table S2: Quantity calculation sheet and their carbon emissions in the construction stage. Figure S1: Carbon emissions in the operational stage. Figure S2: Composition of energy consumption. Figure S3: Composition of fuel consumption. Figure S4: Composition of electricity consumption. Figure S5: Monthly energy consumption. Figure S6: Monthly electricity consumption. Figure S7: Monthly cooling load. Figure S8: Monthly heat load. Figure S9: Annual wind direction (wind speed distribution). Figure S10: Annual wind direction (wind frequency distribution).

Author Contributions: Conceptualization, X.J. and K.L.; methodology, K.L.; software, K.L.; validation, M.L.; formal analysis, K.L.; investigation, K.L. and X.J.; resources, X.J.; data curation, K.L. and V.W.Y.T.; writing-original draft preparation, K.L., H.W., and V.W.Y.T.; writing-review and editing, X.J., B.X. and Q.C.; visualization, M.L.; supervision, X.J.; project administration, X.J.; funding acquisition, X.J.

Funding: The research was supported by the Soft Science Research Plan of Department of Housing and Urban-Rural Development of Anhui Province in China (No. JS2016AHST0011) and by the Innovation Research Plan of Anhui Construction Engineering Group in China (No. W2018JSZX0002).

Acknowledgments: We appreciate the information of the case building provided by the owner and its engineers.

Conflicts of Interest: The authors declare no conflict of interest.

\section{References}

1. Zhang, D.; Zhang, J.; Guo, J.; Xiong, H. A Semantic and Social Approach for Real-Time Green Building Rating in BIM-Based Design. Sustainability 2019, 11, 3973. [CrossRef]

2. Le, K.N.; Tran, C.N.N.; Tam, V.W.Y. Life-Cycle greenhouse-gas emissions assessment: An Australian commercial building perspective. J. Clean. Prod. 2018, 199, 236-247. [CrossRef]

3. Tam, V.W.Y.; Le, K.N.; Tran, C.N.N.; Illankoon, I.M.C.S. A review on international ecological legislation on energy consumption: Greenhouse gas emission management. Int. J. Constr. Manag. 2019, 1-2. [CrossRef]

4. Yang, X.; Hu, M.; Wu, J.; Zhao, B. Building-information-modeling enabled life cycle assessment, a case study on carbon footprint accounting for a residential building in China. J. Clean. Prod. 2018, 183, 729-743. [CrossRef]

5. Cabeza, L.F.; Rincón, L.; Vilariño, V.; Pérez, G.; Castell, A. Life cycle assessment (LCA) and life cycle energy analysis (LCEA) of buildings and the building sector: A review. Renew. Sustain. Energy Rev. 2014, 29, 394-416. [CrossRef]

6. Baek, C.; Tae, S.; Kim, R.; Shin, S. Life Cycle $\mathrm{CO}_{2}$ Assessment by Block Type Changes of Apartment Housing. Sustainability 2016, 8, 752. [CrossRef]

7. Gan, V.J.L.; Deng, M.; Tse, K.T.; Chan, C.M.; Lo, I.M.C.; Cheng, J.C.P. Holistic BIM framework for sustainable low carbon design of high-rise buildings. J. Clean. Prod. 2018, 195, 1091-1104. [CrossRef]

8. Feng, C.; Wang, M. The economy-wide energy efficiency in China's regional building industry. Energy 2017, 141, 1869-1879. [CrossRef]

9. Lee, J.; Tae, S.; Kim, R. A Study on the Analysis of $\mathrm{CO}_{2}$ Emissions of Apartment Housing in the Construction Process. Sustainability 2018, 10, 365. [CrossRef]

10. Li, H.; Deng, Q.; Zhang, J.; Xia, B.; Skitmore, M. Assessing the life cycle $\mathrm{CO}_{2}$ emissions of reinforced concrete structures: Four cases from China. J. Clean. Prod. 2019, 210, 1496-1506. [CrossRef]

11. Norris, G.A. Integrating life cycle cost analysis and LCA. Int. J. Life Cycle Assess. 2001, 6, 118-120.

12. Klüppel, H.-J. ISO 14041: Environmental management-life cycle assessment-goal and scope definitioninventory analysis. Int. J. Life Cycle Assess. 1998, 3, 301. [CrossRef]

13. Chau, C.K.; Leung, T.M.; Ng, W.Y. A review on Life Cycle Assessment, Life Cycle Energy Assessment and Life Cycle Carbon Emissions Assessment on buildings. Appl. Energy 2015, 143, 395-413. [CrossRef]

14. Zhang, X.; Wang, F. Life-Cycle assessment and control measures for carbon emissions of typical buildings in China. Build. Environ. 2015, 86, 89-97. [CrossRef]

15. Peng, C. Calculation of a building's life cycle carbon emissions based on Ecotect and building information modeling. J. Clean. Prod. 2016, 112, 453-465. [CrossRef]

16. Soust-Verdaguer, B.; Llatas, C.; García-Martínez, A. Critical review of bim-based LCA method to buildings. Energy Build. 2017, 136, 110-120. [CrossRef]

17. Basbagill, J.; Flager, F.; Lepech, M.; Fischer, M. Application of life-cycle assessment to early stage building design for reduced embodied environmental impacts. Build. Environ. 2013, 60, 81-92. [CrossRef] 
18. Iddon, C.R.; Firth, S.K. Embodied and operational energy for new-build housing: A case study of construction methods in the UK. Energy Build. 2013, 67, 479-488. [CrossRef]

19. Shadram, F.; Johansson, T.D.; Lu, W.; Schade, J.; Olofsson, T. An integrated BIM-based framework for minimizing embodied energy during building design. Energy Build. 2016, 128, 592-604. [CrossRef]

20. Zhang, Y.; Zheng, X.; Zhang, H.; Chen, G.; Wang, X. Carbon emission analysis of a residential building in China through life cycle assessment. Front. Environ. Sci. Eng. 2016, 10, 150-158. [CrossRef]

21. Li, D.; Cui, P.; Lu, Y. Development of an automated estimator of life-cycle carbon emissions for residential buildings: A case study in Nanjing, China. Habitat Int. 2016, 57, 154-163. [CrossRef]

22. Ramesh, T.; Prakash, R.; Shukla, K.K. Life cycle energy analysis of buildings: An overview. Energy Build. 2010, 42, 1592-1600. [CrossRef]

23. Natephra, W.; Yabuki, N.; Fukuda, T. Optimizing the evaluation of building envelope design for thermal performance using a BIM-based overall thermal transfer value calculation. Build. Environ. 2018, 136, 128-145. [CrossRef]

24. Galiano-Garrigós, A.; García-Figueroa, A.; Rizo-Maestre, C.; González-Avilés, Á. Evaluation of BIM energy performance and $\mathrm{CO}_{2}$ emissions assessment tools: A case study in warm weather. Build. Res. Inf. 2019, 47, 787-812. [CrossRef]

25. Marzouk, M.; Abdelkader, E.M.; Al-Gahtani, K. Building information modeling-based model for calculating direct and indirect emissions in construction projects. J. Clean. Prod. 2017, 152, 351-363. [CrossRef]

26. MOHURD. GB50176-2016 Standard for Thermal Design Code for Civil Building; Ministry of Housing and Urban-Rural Development of the People's Republic of China: Beijing, China, 2016. Available online: http://www.mohurd.gov.cn/wjfb/201702/t20170213_230579.html (accessed on 3 November 2019).

27. Turner, L.K.; Collins, F.G. Carbon dioxide equivalent $\left(\mathrm{CO}_{2}-\mathrm{e}\right)$ emissions: A comparison between geopolymer and OPC cement concrete. Constr. Build. Mater. 2013, 43, 125-130. [CrossRef]

28. Chen, C.; Habert, G.; Bouzidi, Y.; Jullien, A.; Ventura, A. LCA allocation procedure used as an incitative method for waste recycling: An application to mineral additions in concrete. Resour. Conserv. Recycl. 2010, 54, 1231-1240. [CrossRef]

29. Fenner, A.E.; Kibert, C.J.; Woo, J.; Morque, S.; Razkenari, M.; Hakim, H.; Lu, X. The carbon footprint of buildings: A review of methodologies and applications. Renew. Sustain. Energy. Rev. 2018, 94, 1142-1152. [CrossRef]

30. Akbarnezhad, A.; Xiao, J. Estimation and Minimization of Embodied Carbon of Buildings: A Review. Buildings 2017, 7, 5. [CrossRef]

31. Yan, H.; Shen, Q.; Fan, L.C.H.; Wang, Y.; Zhang, L. Greenhouse gas emissions in building construction: A case study of One Peking in Hong Kong. Build. Environ. 2010, 45, 949-955. [CrossRef]

32. Suh, S.; Huppes, G. Methods for Life Cycle Inventory of a product. J. Clean. Prod. 2005, 13, 687-697. [CrossRef]

33. Gardezi, S.S.S.; Shafiq, N. Operational carbon footprint prediction model for conventional tropical housing: A Malaysian prospective. Int. J. Environ. Sci. Technol. 2019, 1-10. [CrossRef]

34. Najjar, M.K.; Figueiredo, K.; Evangelista, A.C.J.; Hammad, A.W.A.; Tam, V.W.Y.; Haddad, A. Life cycle assessment methodology integrated with BIM as a decision-making tool at early-stages of building design. Int. J. Constr. Manag. 2019, 1-15. [CrossRef]

35. Nwodo, M.N.; Anumba, C.J. A review of life cycle assessment of buildings using a systematic approach. Build. Environ. 2019, 162, 106290. [CrossRef]

36. Mateus, R.; Bragança, L. Sustainability assessment and rating of buildings: Developing the methodology SBToolPT-H. Build. Environ. 2011, 46, 1962-1971. [CrossRef]

37. Alshamrani, O.S.; Galal, K.; Alkass, S. Integrated LCA-LEED sustainability assessment model for structure and envelope systems of school buildings. Build. Environ. 2014, 80, 61-70. [CrossRef]

38. Srinivasan, R.S.; Ingwersen, W.; Trucco, C.; Ries, R.; Campbell, D. Comparison of energy-based indicators used in life cycle assessment tools for buildings. Build. Environ. 2014, 79, 138-151. [CrossRef]

39. Vilches, A.; Garcia-Martinez, A.; Sanchez-Montañes, B. Life cycle assessment (LCA) of building refurbishment: A literature review. Energy Build. 2017, 135, 286-301. [CrossRef]

40. Nicolae, B.; George-Vlad, B. Life cycle analysis in refurbishment of the buildings as intervention practices in energy saving. Energy Build. 2015, 86, 74-85. [CrossRef] 
41. Weiler, V.; Harter, H.; Eicker, U. Life cycle assessment of buildings and city quarters comparing demolition and reconstruction with refurbishment. Energy Build. 2017, 134, 319-328. [CrossRef]

42. Islam, H.; Jollands, M.; Setunge, S. Life cycle assessment and life cycle cost implication of residential buildings-A review. Renew. Sustain. Energy. Rev. 2015, 42, 129-140. [CrossRef]

43. Mostavi, E.; Asadi, S.; Boussaa, D. Development of a new methodology to optimize building life cycle cost, environmental impacts, and occupant satisfaction. Energy 2017, 121, 606-615. [CrossRef]

44. Hoogmartens, R.; Van Passel, S.; Van Acker, K.; Dubois, M. Bridging the gap between LCA, LCC and CBA as sustainability assessment tools. Environ. Impact Assess. Rev. 2014, 48, 27-33. [CrossRef]

45. Guggemos Angela, A.; Horvath, A. Decision-Support Tool for Assessing the Environmental Effects of Constructing Commercial Buildings. J. Arch. Eng. 2006, 12, 187-195. [CrossRef]

46. Junnila, S.; Horvath, A.; Guggemos Angela, A. Life-Cycle Assessment of Office Buildings in Europe and the United States. J. Infrastruct. Syst. 2006, 12, 10-17. [CrossRef]

47. Wan Omar, W.-M.-S.; Doh, J.-H.; Panuwatwanich, K. Variations in embodied energy and carbon emission intensities of construction materials. Environ. Impact Assess. Rev. 2014, 49, 31-48. [CrossRef]

48. Roh, S.; Tae, S. An integrated assessment system for managing life cycle $\mathrm{CO}_{2}$ emissions of a building. Renew. Sustain. Energy Rev. 2017, 73, 265-275. [CrossRef]

49. Onat, N.C.; Kucukvar, M.; Tatari, O. Scope-based carbon footprint analysis of U.S. residential and commercial buildings: An input-output hybrid life cycle assessment approach. Build. Environ. 2014, 72, 53-62. [CrossRef]

50. Li, X.; Zhu, Y.; Zhang, Z. An LCA-based environmental impact assessment model for construction processes. Build. Environ. 2010, 45, 766-775. [CrossRef]

51. Ylmén, P.; Peñaloza, D.; Mjörnell, K. Life Cycle Assessment of an Office Building Based on Site-Specific Data. Energies 2019, 12, 2588. [CrossRef]

52. Cavalliere, C.; Habert, G.; Dell'Osso, G.R.; Hollberg, A. Continuous BIM-based assessment of embodied environmental impacts throughout the design process. J. Clean. Prod. 2019, 211, 941-952. [CrossRef]

53. Santos, R.; Costa, A.A.; Silvestre, J.D.; Pyl, L. Integration of LCA and LCC analysis within a BIM-based environment. Autom. Constr. 2019, 103, 127-149. [CrossRef]

54. Röck, M.; Hollberg, A.; Habert, G.; Passer, A. LCA and BIM: Visualization of environmental potentials in building construction at early design stages. Build. Environ. 2018, 140, 153-161. [CrossRef]

55. Schultz, J.; Ku, K.; Gindlesparger, M.; Doerfler, J. A benchmark study of BIM-based whole-building life-cycle assessment tools and processes. Int. J. Sustain. Build. Tech. Urban Dev. 2016, 7, 219-229. [CrossRef]

56. Solís-Guzmán, J.; Rivero-Camacho, C.; Alba-Rodríguez, D.; Martínez-Rocamora, A. Carbon footprint estimation tool for residential buildings for non-specialized users: OERCO2 project. Sustainability 2018, 10, 1359. [CrossRef]

57. Soust-Verdaguer, B.; Llatas, C.; García-Martínez, A.; Gómez De Cózar, J.C. BIM-Based LCA Method to Analyze Envelope Alternatives of Single-Family Houses: Case Study in Uruguay. J. Arch. Eng. 2018, 24, 05018002. [CrossRef]

58. Wang, J.; Wu, H.; Duan, H.; Zillante, G.; Zuo, J.; Yuan, H. Combining life cycle assessment and Building Information Modelling to account for carbon emission of building demolition waste: A case study. J. Clean. Prod. 2018, 172, 3154-3166. [CrossRef]

59. Bonamente, E.; Cotana, F. Carbon and Energy Footprints of Prefabricated Industrial Buildings: A Systematic Life Cycle Assessment Analysis. Energies 2015, 8, 12685-12701. [CrossRef]

60. Teng, Y.; Pan, W. Systematic embodied carbon assessment and reduction of prefabricated high-rise public residential buildings in Hong Kong. J. Clean. Prod. 2019, 238, 117791. [CrossRef]

61. Dong, L.; Wang, Y.; Li, X.H.; Jiang, B.; Al-Hussein, M. Carbon Reduction Measures-Based LCA of Prefabricated Temporary Housing with Renewable Energy Systems. Sustainability 2018, 10, 718. [CrossRef]

62. Švajlenka, J.; Kozlovská, M. Houses Based on Wood as an Ecological and Sustainable Housing Alternative-Case Study. Sustainability 2018, 10, 1502. [CrossRef]

63. Švajlenka, J.; Kozlovská, M.; Pošiváková, T. Analysis of Selected Building Constructions Used in Industrial Construction in Terms of Sustainability Benefits. Sustainability 2018, 10, 4394. [CrossRef]

64. Švajlenka, J.; Kozlovská, M. Effect of accumulation elements on the energy consumption of wood constructions. Energy Build. 2019, 198, 160-169. [CrossRef]

65. Liu, S.; Meng, X.; Tam, C. Building information modeling based building design optimization for sustainability. Energy Build. 2015, 105, 139-153. [CrossRef] 
66. Zhang, S.; Chan, A.P.C.; Feng, Y.; Duan, H.; Ke, Y. Critical review on PPP Research-A search from the Chinese and International Journals. Int. J. Proj. Manag. 2016, 34, 597-612. [CrossRef]

67. MOHURD. GB/T51366-2019 Standard for Building Carbon Emission Calculation; Ministry of Housing and Urban-Rural Development of the People's Republic of China: Beijing, China, 2019. Available online: http://www.mohurd.gov.cn/wjfb/201905/t20190530_240723.html (accessed on 3 November 2019).

68. Wong, J.K.W.; Kuan, K.L. Implementing 'BEAM Plus' for BIM-based sustainability analysis. Autom. Constr. 2014, 44, 163-175. [CrossRef]

69. Inyim, P.; Rivera, J.; Zhu, Y. Integration of building information modeling and economic and environmental impact analysis to support sustainable building design. J. Manag. Eng. 2014, 31. [CrossRef]

70. Najjar, M.; Figueiredo, K.; Palumbo, M.; Haddad, A. Integration of BIM and LCA: Evaluating the environmental impacts of building materials at an early stage of designing a typical office building. J. Build. Eng. 2017, 14, 115-126. [CrossRef]

71. Stadel, A.; Eboli, J.; Ryberg, A.; Mitchell, J.; Spatari, S. Intelligent sustainable design: Integration of carbon accounting and building information modeling. J. Prof. Issues Eng. Educ. Pract. 2011, 137, 51-54. [CrossRef]

72. Lu, K.; Wang, H. Estimation of Building's Life Cycle Carbon Emissions Based on Life Cycle Assessment and Building Information Modeling: A Case Study of a Hospital Building in China. J. Geosci. Environ. Prot. 2019, 7,147-165. [CrossRef]

73. Hua, H.; Wang, X.; Deng, P.; He, J.; Chen, C.; Zeng, B.; Zhang, X.; Zhang, Y. Study on Low-Carbon Design Analysis and Carbon Emission Measure of Public Building Based on BIM (in Chinese). J. Civ. Eng. Manag. 2014, 31, 62-67.

74. Cao, D.; Wang, G.; Li, H.; Skitmore, M.; Huang, T.; Zhang, W.; Skitmore, R. Practices and effectiveness of building information modelling in construction projects in China. Autom. Constr. 2015, 49, 113-122. [CrossRef]

75. Wong, K.-D.; Fan, Q.; Wong, K. Building information modelling (BIM) for sustainable building design. Facilities 2013, 31, 138-157. [CrossRef]

76. Eleftheriadis, S.; Duffour, P.; Mumovic, D. BIM-embedded life cycle carbon assessment of RC buildings using optimised structural design alternatives. Energy Build. 2018, 173, 587-600. [CrossRef]

77. Biswas, W.K. Carbon footprint and embodied energy consumption assessment of building construction works in Western Australia. Int. J. Sustain. Environ. 2014, 3, 179-186. [CrossRef] 